\title{
SAFE SEX BEHAVIOR AMONG COMMERCIAL SEX WORKERS IN BANJARSARI, SURAKARTA, CENTRAL JAVA, AND ITS ASSOCIATED FACTORS
}

\author{
Maecelina Hestin Ambarsari'1), Argyo Demartoto²), \\ C.S.P Wekadigunawan ${ }^{3}$ )
}

1) Masters Program in Public Health, Universitas Sebelas Maret

2) Faculty of Social and Political Sciences, Universitas Sebelas Maret

3) Faculty of Medicine, Universitas Sebelas Maret

\begin{abstract}
Background: Worldwide it is estimated that more than one million people in contract sexually-transmitted disease (STDs) everyday. Annually approximately 357 million new infections occur by one of four STDs: chlamidia, gonorrhea, syphilis, and mouth ulcer. The incidence of HIV/AIDS has been increasing year by year. HIV/AIDS has spread in 407 of 507 districts and municipalities in Indonesia, or equivalently covering $80 \%$ districts and municipalities of the country. In Surakarta, the cumulative incidence of HIV/AIDS from 2005 to 2017 was 561 cases, with 38 HIV cases and 46 AIDS cases in 2017 alone. Safe sex is important to prevent pregnancy, STDs, and most importantly HIV and AIDS. This study aimed to examine factors associated with safe sex behavior among commercial sex workers in Banjarsari, Surakarta, Central Java.
\end{abstract}

Subjects and Method: This was a cross-sectional study conducted in Banjarsari Sub-district, Surakarta, Central Java. A total sample of 100 commercial sex workers was selected by stratified random sampling. The dependent variable was safe sex behavior. The independent variables were knowledge of STDs and HIV/AIDS, self efficacy, condom availability, access to health care service, health personnel support, and peer support. The data were collected by questionnaire and analyzed by a multiple linear regression.

Results: Safe sex behavior was associated with good knowledge of STDs and HIV/AIDS $(b=0.19 ; 95 \% \mathrm{CI}=0.01$ to $0.30 ; \mathrm{p}=0.032)$, strong self efficacy $(b=$ $0.18 ; 95 \% \mathrm{CI}=0.01$ to $0.38 ; \mathrm{p}=0.047)$, condom availability $(\mathrm{b}=0.30 ; 95 \% \mathrm{CI}=$ 0.36 to $1.20 ; \mathrm{p}<0.001)$, good access to health care service $(\mathrm{b}=0.19 ; 95 \% \mathrm{CI}=0.02$ to $0.52 ; \mathrm{p}=0.035)$, strong health personnel support $(\mathrm{b}=0.18 ; 95 \% \mathrm{CI}=0.01$ to $0.57 ; \mathrm{p}=0.041)$, strong peer support $(\mathrm{b}=0.17 ; 95 \% \mathrm{CI}=0.01$ to $0.50 ; \mathrm{p}=0.046)$.

Conclusion: Safe sex behavior is associated with good knowledge of STDs and HIV/AIDS, strong self efficacy, condom availability, access to health care service, strong health personnel support, and strong peer support.

Keywords: safe sex behavior, knowledge, self efficacy, condom availability, access to health service, health personnel support, peer support

\section{Correspondence:}

Maecelina Hestin Ambarsari. Masters Program in Public Heath, Universitas Sebelas Maret, Jl. Ir. Sutami 36 A, Surakarta 57126, Central Java.

Email: hestinmaecelina@gmail.com.Mobile: +6285742975078. 